\title{
The analysis of the differences between the results of the thermal response test and the data from the operation of the brine-to-water heat pump's vertical exchanger
}

\author{
Natalia Fidorów-Kaprawy ${ }^{1,}$, Ewelina Stefanowicz ${ }^{1}$, Wojciech Mazurek ${ }^{1}$, Małgorzata \\ Szulgowska-Zgrzywa ${ }^{1}$, and Anna Bryszewska-Mazurek ${ }^{1}$ \\ ${ }^{1}$ Wroclaw University of Science and Technology, Faculty of Environmental Engineering, \\ Wybrzeże Wyspiańskiego 27, 50-370 Wrocław, Poland
}

\begin{abstract}
The article discusses the principles and the problems of obtaining an accurate data input for the design of brine-to-water heat pump's vertical exchangers. Currently, the most accurate method is the thermal response test (TRT). Unfortunately, the test procedure has its limitations and the quality of the results depends on many factors that cannot be fully controlled during the test. As an illustration of the problems, the results of the TRT were presented. The test was executed on the vertical boreholes (one actively regenerated and one not actively regenerated during the summer) which are parts of the operating heat pump system. The test results were compared to the data from the device's operation, in particular with the measurements of the undisturbed ground temperature profiles and the actual unit energy gains from the boreholes. The level of difference between the results of the test and the data from the operation of the boreholes under the real load and the threats concerning the boreholes overload were shown. Additionally the performance differences between the actively regenerated and not actively regenerated boreholes have been emphasised.
\end{abstract}

\section{Introduction}

The thermal response test (TRT) is one of the basic tools that allow for the ground parameters data acquisition in the process of the heat pumps' low heat sources design. The procedure of the tests conducted nowadays does not differ much from one developed by Mogensen in 1983 [1]. The general application of TRT as the examination of the ground thermal conductivity found use in 90's and very quickly become the important diagnostic tool. The borehole heat transfer ability may vary in a large extent. It may be in range from 10 to $100 \mathrm{~W} / \mathrm{m}$ depending on the local geological conditions, the probe type, the quality and the application precision of the filling between the pipes and the ground [2]. The TRT involves making the test borehole or boreholes (in case of the bigger installations) and the

\footnotetext{
${ }^{*}$ Corresponding author: natalia.fidorow@pwr.edu.pl
} 
measurement of the effective ground thermal conductivity - it covers the thermal conductivity of the ground as well as the pipe and the filling. The heat transferring agent, transporting known amount of heat is pumped into the borehole. The flow and return parameters are registered. The measurement is carried out until the achievement of the stabilization of the heat flow in the ground; usually 50 to 70 hours $(2-3$ days $)[1,3]$. The test results, according to the information found in literature, while maintaining the required test conditions assure the precision of the ground thermal conductivity estimation on the level of $10 \%[4,5]$, what significantly raises the accuracy of the brine-to-water heat pump's vertical boreholes length design. The main problems and restrictions regarding the TRT procedure concern: the measurement of the undisturbed ground temperature profile, the heating power stabilization during the test, the measurement duration, the influence of the advection and the ground water flow on the measurement, the influence of the instantaneous weather conditions, the influence of the transition heat loss and the quality of the borehole and the filling application. In this paper the issues concerning the measurement of the undisturbed ground temperature profile and the ground water flow will be discussed.

There are a few methods for the measurement of the undisturbed ground temperature for the purpose of TRT. It should be noticed that the borehole heat resistance determined by TRT is very sensitive to the undisturbed ground temperature value. Usually this measurement is carried out by the slow pumping of the heat transferring agent through the borehole and the fluid temperature measurement. To increase the accuracy of the measurement it is recommend in [6] immersing the temperature sensor in the pipe and measuring the temperature on various depths. In the literature, more methods are described: for example using the immersed sensors or the optical fibres. However, they are not popular because of the procedure cost increase.

The mobile TRT is mainly used for the determination of the effective thermal conductivity of the ground. It should be kept in mind that the ground is a heterogeneous form. The thermal conductivity might vary with the depth. Moreover, the heat transfer in the ground is not only in the form of conduction and may be influenced by the ground water flow or advection. As a result, the thermal conductivity measured during TRT may contain some information concerning those factors influence and it is better to call it the effective thermal conduction. According to [7] the ground water flow influences the TRT results. The results of the simulations [8] proved, a that relatively low flow rate may significantly increase the heat transfer. In the article [9] the TRT simulation had been performed using two-dimensional models of the borehole and the ground. The tests had been simulated using various values of the $\mathrm{U}$ coefficient (characterizing the flow rate of the ground water, expressed in $\mathrm{m} / \mathrm{s}$ ). Generally, the higher flow coefficient, the more the TRT result (the effective conductivity) differed upwards from the ground thermal conductivity. At the same time, the lower was the thermal conductivity of the ground the greater was the influence of the ground water flow on the TRT results.

Basing on that research it should be noticed that the results of the test conducted under the occurrence of ground water flow may significantly alter the assumptions made for the design purposes and cause the operational problems. In this paper authors decided to show the extent of the problem using the exemplary installation. Data serving as the illustration of the problem have been obtained during the TRT tests conducted on the boreholes which are parts of operating heat pump system. The outcomes of the test procedure have been presented and compared with the system operational data, particularly with the measurements of the real temperature profiles of the boreholes and the real specific energy extraction rates. The level of divergence among the test results and the operational data of the system working under the real load has been presented. As the examined system, apart from the measurement devices, has the possibility of boreholes' regeneration, the TRTs 
were performed on two boreholes: the one which is actively regenerated during summer (Borehole 1) and the one which is not actively regenerated (Borehole 3). The results of TRT and the operational data analysis have been compared for those two boreholes.

\section{Installation and measuring devices}

The system on which the study and the analysis have been performed acts as the heat source for the CTE (Energy Technology Centre) office building in Świdnica since 2012. The underfloor heating system works for the $533 \mathrm{~m}^{2}$ building ground floor area and is designed to deliver around 24.6 MWh of energy during the heating season. The energy is delivered by the BW 117 type brine-to-water heat pump with the nominal thermal power of $17.6 \mathrm{~kW}$, the cooling capacity of $13.8 \mathrm{~kW}$ and the COP of 4.4 (B0/W35). The low heat source consists of five boreholes (the single U-pipe (PE $40 \times 4.0 \mathrm{~mm}$ ) surrounded by bentonite filler), each $78 \mathrm{~m}$ deep, $6 \mathrm{~m}$ apart. The heat transferring agent is the propylene glycol solution in water $\left(1032 \mathrm{~kg} / \mathrm{m}^{3}, 3900 \mathrm{~kJ} /(\mathrm{kg} \cdot \mathrm{K})\right.$, concentration $\left.34 \%\right)$. Three boreholes are equipped in measuring devices. There are Pt 1000 type, class B (permissible deviation $\pm 0.3 \mathrm{~K}$, standard deviation for a B type measurement is $0.17 \mathrm{~K}$ ) temperature sensors located every 5 meters about $10 \mathrm{~cm}$ from the polyethylene pipe in the bentonite (16 pieces in each borehole). In the boreholes' measurement wells there are the Endress\&Hausner Proline PROMAG electromagnetic flow meters (1\% accuracy) and Endress\&Hausner Omnigrad M TST90 coupled temperature sensors (accuracy of a temperature difference measurement of $\pm 0.05 \mathrm{~K}$ and an individual sensor accuracy of $\left.\pm(0.15+0.002 \cdot|\mathrm{t}|)^{\circ} \mathrm{C}\right)$. The summary volumetric flow in the system is around $2.8 \mathrm{~m}^{3} / \mathrm{h}$ (the minimum flow rate for the heat pump is $2541.4 \mathrm{l} / \mathrm{h}$ ). The assumed flow rate for each borehole in case of 5 boreholes performance is around $0.55 \mathrm{~m}^{3} / \mathrm{h}$ (the real operational data are $0.51 \mathrm{~m}^{3} / \mathrm{h}$ for the tested boreholes number 1 and 3 ). In case of 3 boreholes performance (for the purpose of the research) the flows are: in the borehole number $1-1.02 \mathrm{~m}^{3} / \mathrm{h}$ and for the borehole number $3-0.98 \mathrm{~m}^{3} / \mathrm{h}$.

\section{Thermal response test}

The thermal response tests presented in this article were conducted in October 2015. Tests were carried for two boreholes: actively regenerated during the summer Borehole 1 and not actively regenerated Borehole 3 . During each test the fluid temperature changes and the flow rate was recorded as a function of time $(\mathrm{t})$. The test consisted of three parts. The objective of the first part of the test was to determine the undisturbed ground temperature. The measurement was carried out using sensors mounted in the measurement well and by slow fluid pumping $\left(0.15 \mathrm{~m}^{3} / \mathrm{h}\right)$. The next stage concerned the parameters' stabilization. It was carried out with the flow matching the operational values $\left(0.55 \mathrm{~m}^{3} / \mathrm{h}\right)$ and lasted for about 12 hours. The stabilization step had been followed by the proper measurement. The borehole model which enables the determination of the thermal conductivity of the ground is created basing on this last measurement step. The calculations were made based on the borehole linear model described by the equation 1 [10].

$$
T(t)=(Q / 4 \cdot \pi \cdot H \cdot \lambda) \cdot\left[\ln \left(4 \cdot a \cdot t / r^{2}\right)-0.5772\right]+R_{b} \cdot(Q / H)+T_{0}
$$

where: $T$ - mean fluid temperature $\left({ }^{\circ} \mathrm{C}\right), t-$ time $(\mathrm{h}), Q-\operatorname{specific}$ heat load $(\mathrm{W})$, $H$ - borehole depth $(\mathrm{m}), \lambda$ - effective ground thermal conductivity $(\mathrm{W} /(\mathrm{m} \cdot \mathrm{K})), a-$ thermal diffusivity $\left(\mathrm{m}^{2} / \mathrm{h}\right), R_{b}$ - effective borehole thermal resistance $\left.(\mathrm{m} \cdot \mathrm{K}) / \mathrm{W}\right), T_{0}$ - undisturbed ground temperature $\left({ }^{\circ} \mathrm{C}\right), r$ - radial distance from line source $(\mathrm{m})$. 
Figure 1 shows the results of the first measurement step, which was the slow brine pumping through the borehole (temperature measured in the well), compared with the measurements made by the temperature sensors in borehole (temperature measured in the borehole). In the figure, the considerable differences in both measurement results are visible. The ground water impact on the temperature profile has been significant. The measurement results enable the calculation of approximate average temperature of the borehole. In addition it has been observed that, the mean temperature of the actively regenerated Borehole 1 is about $1 \mathrm{~K}$ higher than the not regenerated Borehole 3.

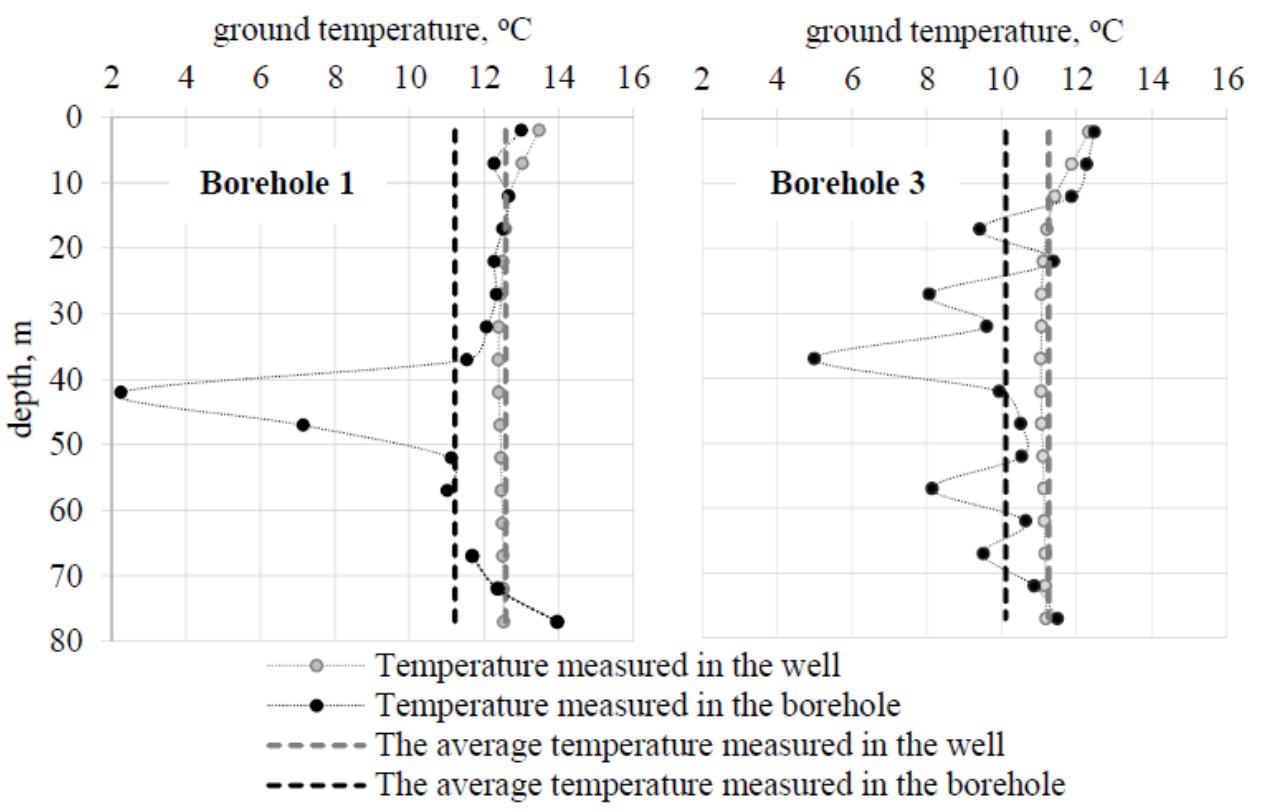

Fig. 1. The undisturbed ground temperature profile in Boreholes 1 and 3.

The figure 2 shows the TRT results for two heat pump's boreholes (actively regenerated Borehole 1 and not actively regenerated Borehole 3). Basing on TRT measurement data a graph in semi logarithmic coordinate system was created. The graph enables to designate a straight trend line of the measurement results' last part (after 12 hours of measurement). The equation describing this line is [10]:

$$
T(t)=s \cdot \ln t+b
$$

The slope of the trend line determines the value of the average effective thermal conductivity of the ground, which was calculated using equation (3) [10]:

$$
\lambda=q_{0} /(4 \cdot \pi \cdot s)=m \cdot C_{f} \cdot\left(T_{1}-T_{2}\right) /(4 \cdot \pi \cdot H \cdot s)
$$

where: $s$ - slope of the trend line, $b$ - constant, $m$ - mass flow rate of the brine $(\mathrm{kg} / \mathrm{s})$, $q_{0}-$ specific heat load $(\mathrm{W} / \mathrm{m}) ; C_{f}-$ specific heat $(\mathrm{kJ} /(\mathrm{kg} \cdot \mathrm{K})), T_{l}-$ inlet brine temperature $\left({ }^{\circ} \mathrm{C}\right), T_{2}$ - outlet brine temperature $\left({ }^{\circ} \mathrm{C}\right)$ 


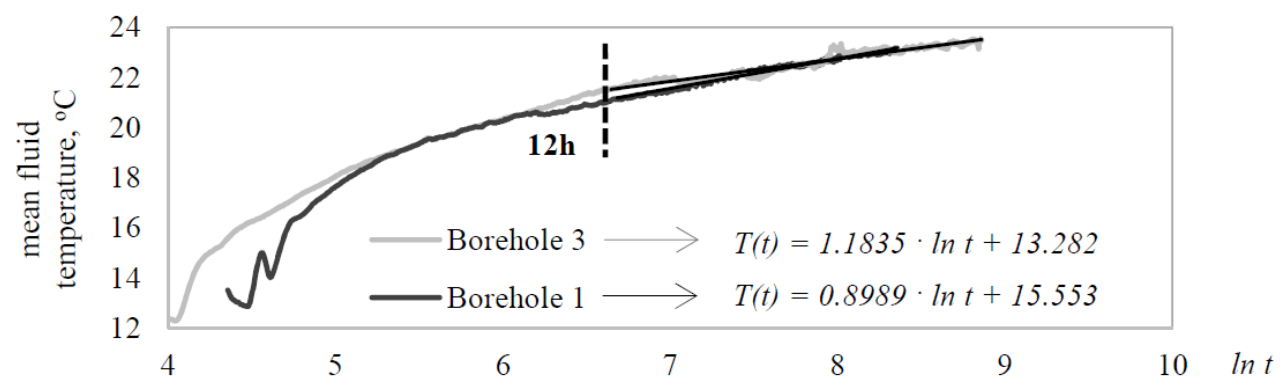

Fig. 2. The brine temperature recorded during TRT in boreholes 1 and 3 .

The estimated values of thermal conductivity are presented below. The difference in the values of thermal conductivity of ground may be caused by the intense flow of ground water (observed in both boreholes) but it might be also a result of the active regeneration of the Borehole 1. The tests lasted for $115 \mathrm{~h}$ for the first borehole and for $70 \mathrm{~h}$ for the third borehole (measurement time is much longer than suggested in the literature), despite that the stabilisation of the temperature had not been achieved. It should therefore be noted that the disorders resulting from the groundwater flow in the area under the study are of the great importance from the point of view of system design, which has a direct impact on its size and subsequent its costs both investment and operational.

Table 1. TRT measurements and calculations results.

\begin{tabular}{|c|c|c|}
\hline & Borehole 1 & Borehole 3 \\
\hline Effective ground thermal conductivity, $(\mathrm{W} /(\mathrm{m} \cdot \mathrm{K}))$ & 4.18 & 3.09 \\
\hline Specific heat load, $(\mathrm{W} / \mathrm{m})$ & 47.2 & 45.86 \\
\hline Mass flow rate, $(\mathrm{kg} / \mathrm{s})$ & 0.15 & 0.14 \\
\hline Trend line slope & 0.8989 & 1.1835 \\
\hline
\end{tabular}

Calculated ground conduction coefficient values allow for assumption of the specific power extraction rates basing on which the length of ground heat exchanger is designed. In the literature there are a few references assigning the specific power extraction rates per meter of the borehole to the ground thermal conductivity coefficients. Basing on the literature references, the unit yield for the tested boreholes should be about $55 \mathrm{~W} / \mathrm{m}$ [11] (according to the recommendations for $2000 \mathrm{~h}$ ). In order to verify the theoretical parameters of the ground, in the following part of this article the results of increasing the low heat source extraction rate to the value resulting from TRT have been presented.

\section{The measurements of the heat pumps' low heat source performance}

As mentioned before the analysed brine-to-water heat pump installation had been operated with five 78 meters long boreholes serving as the low heat source. The source size results in maximum borehole energy extraction rate $\mathrm{q}_{\max }=35 \mathrm{~W} / \mathrm{m}$ which is the effect of the heat pump's cooling power. For the purposes of the TRT results verification the change in the system operation had been implemented and two out of five boreholes had been cut off. As a result the maximum borehole extraction rate should have risen to $\mathrm{q}_{\max }=60 \mathrm{~W} / \mathrm{m}$. Boreholes number 1(actively regenerated) and 3 (not actively regenerated) underwent the detailed analysis.

In figures 3 and 4 the system performance in subsequent labour cycles have been presented (the heat pump labour cycle is defined as the period from the compressor 
switching on to its switching off). The calculations have been performed in one-minute step and afterwards averaged in subsequent labour cycles. The ambient air temperature $\left(\mathrm{T}_{\mathrm{a}}\right)$, the brine temperature at the borehole number 1 and 3 outlet $\left(T_{\text {brine, } 1}\right.$ and $\left.T_{\text {brine, } 3}\right)$ and the average power specific extraction rate of the boreholes number 1 and $3\left(\mathrm{q}_{(\mathrm{B} 1) \text { avg }}\right.$ and $\left.\mathrm{q}_{(\mathrm{B} 3) \text { avg }}\right)$ have been calculated. The maximum power specific extraction rate taken from Borehole 1 and $3\left(\mathrm{q}_{(\mathrm{B} 1) \max }\right.$ and $\left.\mathrm{q}_{(\mathrm{B} 3) \max }\right)$ have been also determined for each labour cycle.

\subsection{Operation with five boreholes}

The performance of the low heat source of the brine-to-water heat pump is presented in the Figure 3. The ambient air temperature $\left(\mathrm{T}_{\mathrm{a}}\right)$ during two weeks presented in the Figure 3 (at the turn of December 2014 and January 2015) ranged between $+10^{\circ} \mathrm{C}$ and $-10^{\circ} \mathrm{C}$. The Borehole1 maximum power specific extraction rate was around $\mathrm{q}_{(\mathrm{B} 1) \max }=39 \mathrm{~W} / \mathrm{m}$ and Borehole $3-$ around $\mathrm{q}_{(\mathrm{B} 3) \max }=33 \mathrm{~W} / \mathrm{m}$. The average power extraction rate for boreholes also differed one from another and were around 4-5 W/m greater for Borehole 1. When the ambient air temperature was low, the average power extraction rates of boreholes have been getting close to the maximum values. Despite the greater load of the Borehole 1 , the brine temperature on this borehole outlet $\left(\mathrm{T}_{\text {brine, }, 1}\right)$ was higher than for the Borehole 3 ( $\mathrm{T}_{\text {brine, } 3) \text {. }}$

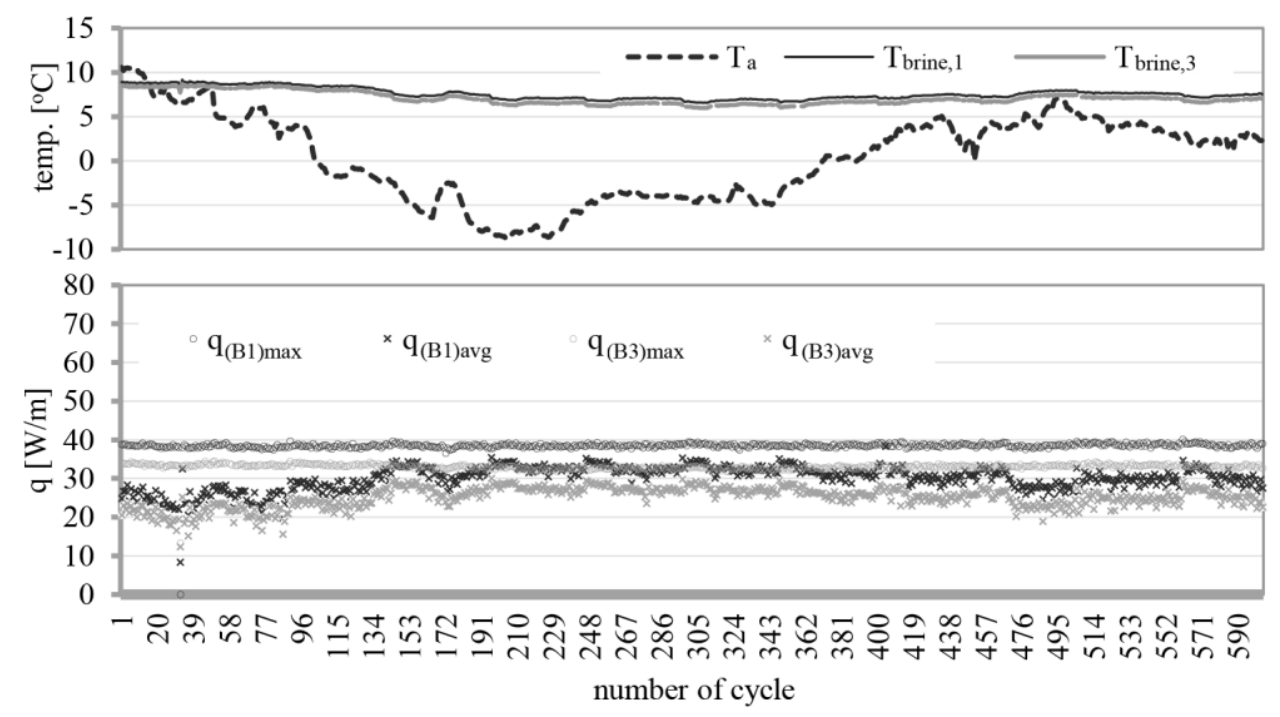

Fig. 3. The exploitation of the heat pump's energy source with five boreholes (two weeks of the operation in December 2014 and January 2015). 


\subsection{Operation with three boreholes}

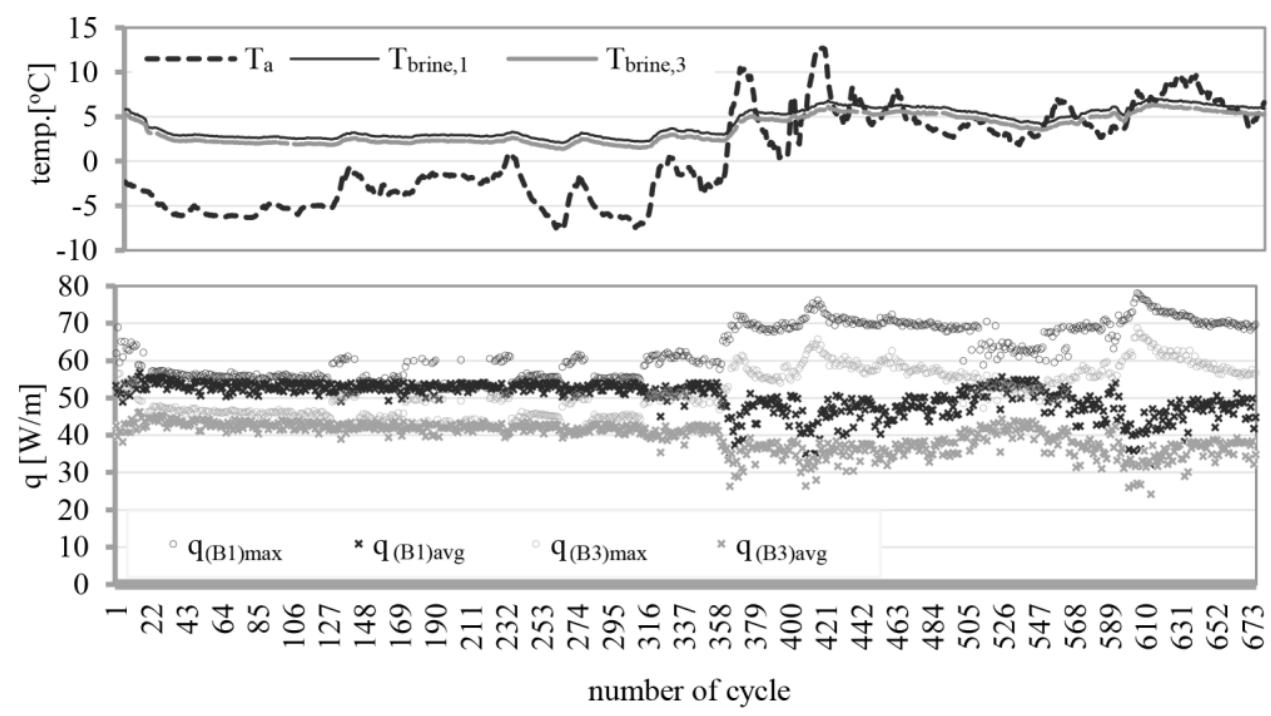

Fig. 4. The exploitation of the heat pump's energy source with five boreholes (two weeks of the operation in February 2017).

The performance of the brine-to-water heat pump's low heat source (operation with three boreholes) is presented in the Figure 4. The ambient air temperature $\left(\mathrm{T}_{\mathrm{a}}\right)$ during two weeks presented in the Figure 4 (February 2017) also ranged between $+10^{\circ} \mathrm{C}$ and $-10^{\circ} \mathrm{C}$. The Borehole 1 maximum power specific extraction rate was around $\mathrm{q}_{(\mathrm{B} 1) \max }=70 \mathrm{~W} / \mathrm{m}$ and Borehole 3 - around $\mathrm{q}_{(\mathrm{B} 3) \max }=60 \mathrm{~W} / \mathrm{m}$. The average power extraction rate for boreholes also differed one from another and were around $10 \mathrm{~W} / \mathrm{m}$ higher for Borehole 1 . When the ambient air temperature was low, the average power extraction rates of boreholes also had been getting close to the maximum values. At the same time the increase of the load made the maintenance of the long-term power extraction rate on the level of $60-70 \mathrm{~W} / \mathrm{m}$ impossible. Such operation results in the brine temperature decrease at the boreholes outlets form $7-8^{\circ} \mathrm{C}$ (typical for the examined installation) to $2^{\circ} \mathrm{C}$. Despite the greater load of the borehole number 1 , the brine temperature on this borehole outlet $\left(\mathrm{T}_{\text {brine, } 1}\right)$ is higher than for the borehole number 3 ( $\left.\mathrm{T}_{\text {brine, } 3}\right)$.

\subsection{Discussion}

The measurement outcomes summary of the heat pump's low heat source working with five and three boreholes are set together in Table 3. The outcomes concern the borehole number 1 (actively regenerated) and 3 (not actively regenerated). The summary applies to the periods illustrated in Figures 3 and 4. The average ambient air temperature and hence the average heat load have been approximately equal in both cases. When the system is operated with five boreholes, the maximum specific power extraction rates reach $38.5 \mathrm{~W} / \mathrm{m}$. In case of the actively regenerated borehole this value is about $20 \%$ higher than for not actively regenerated one. Switch to the operation with three boreholes alters the boreholes specific power extraction rates significantly. They increase by more than $50 \%$ for the Borehole 3 and more than $60 \%$ for the Borehole 1 . In neither of the cases the parameters that allow for the brine temperature maintenance on the level characteristic for the operation with five boreholes are not achieved. The temperature falls by more than $50 \%$. At the same time it may be noticed that the influence of the borehole regeneration is greater for 
the system operated with three boreholes. The heat output of the regenerated borehole is $27 \%$ higher in this operation type, than the not actively regenerated one.

Table 2. The summary of the system with three and five boreholes performance data.

\begin{tabular}{|l|c|c|c|c|c|c|c|}
\hline & \multicolumn{3}{|c|}{ Borehole 1 } & \multicolumn{3}{c|}{ Borehole 3 } & \\
\hline & $\mathrm{q}_{\max }$ & $\mathrm{q}_{\text {cycle }}$ & $\mathrm{T}_{\mathrm{B}, \text { avg }}$ & $\mathrm{q}_{\max }$ & $\mathrm{q}_{\text {cycle }}$ & $\mathrm{T}_{\mathrm{B} \text {,avg }}$ & $\mathrm{T}_{\mathrm{a}}$ \\
\hline type of exploitation & $\mathrm{W} / \mathrm{m}$ & $\mathrm{W} / \mathrm{m}$ & ${ }^{\circ} \mathrm{C}$ & $\mathrm{W} / \mathrm{m}$ & $\mathrm{W} / \mathrm{m}$ & ${ }^{\circ} \mathrm{C}$ & ${ }^{\circ} \mathrm{C}$ \\
\hline five boreholes & 38.5 & 30.1 & 7.6 & 33.1 & 25.1 & 7.1 & 0.4 \\
\hline borehole 1/borehole 3 & $116 \%$ & $120 \%$ & $107 \%$ & - & - & - & - \\
\hline three boreholes & 62.5 & 50.2 & 4.3 & 51.7 & 39.5 & 3.6 & 0.4 \\
\hline borehole 1/borehole 3 & $121 \%$ & $127 \%$ & $119 \%$ & - & - & - & - \\
\hline three / five boreholes & $162 \%$ & $167 \%$ & $57 \%$ & $156 \%$ & $157 \%$ & $51 \%$ & $100 \%$ \\
\hline
\end{tabular}

Due to the necessity of the heating maintenance with the high heat pump's efficiency it is extremely important to achieve the suitable specific power extraction rates of the borehole. The ground overload and failure to maintain the appropriate specific power extraction rate will quickly result in the excessive fall of the temperature of the brine (glycol solution in water) leaving the boreholes. In Figure 5 the relation between the brine temperature and the ambient air temperature in analysed periods and examined boreholes for both operation configurations have been presented. Two effects can be observed while analysing the charts: the brine temperature is higher at the outlet of borehole with regeneration (regardless of the operation mode) and the change in the trend line slope when changing the operation mode from 5 to 3 boreholes.
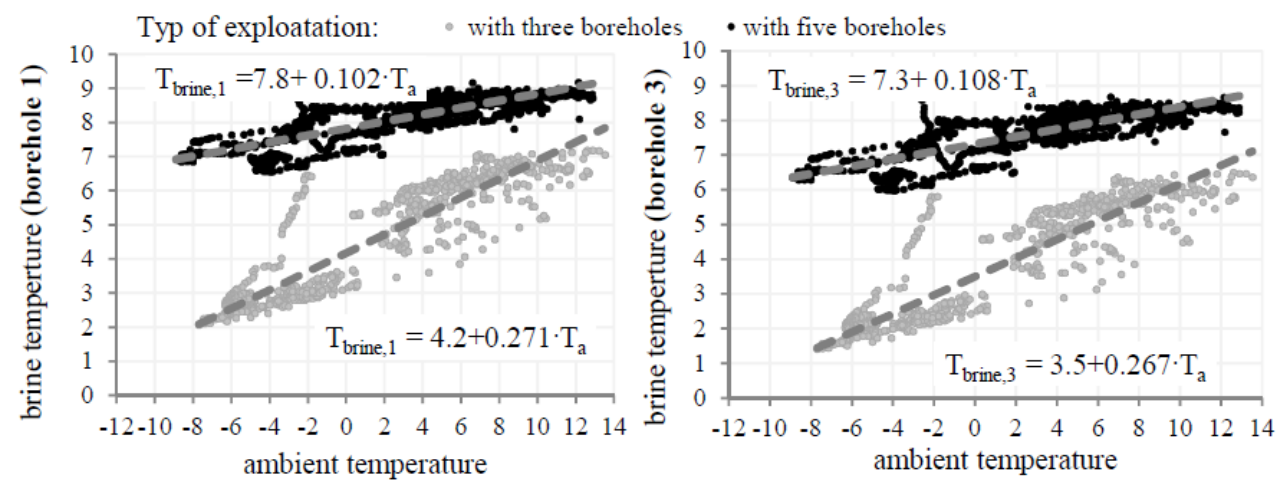

Fig. 5. The relation between the ambient air temperature and brine temperature in heat pump system.

\section{Conclusions}

The achievement of the specific power extraction rates received basing on the TRT results was not achieved during operation in examined installation. The low heat source load increase results in the severe brine temperature drop both in actively regenerated and not regenerated boreholes' outlets. In the case of exploitation with three boreholes, the analysis results show the strong relation between the external temperature (defining the building thermal load) and the brine temperature at the boreholes' outlets, which will influence the system operational conditions in following years. The ground water flow is the important factor that influences the accuracy and disturbs measurement results of TRT performed on the examined system. Both the TRT results as well as the outcomes of performed analyses show the differences of the regenerated and not actively regenerated boreholes, proving the benefits resulting from the energy storage in summer. 


\section{References}

1. J.D. Spitler, S.E.A. Gehlin, Renew. Sust. Energ. Rev. 50, 1125-1137 (2015)

2. J. Acuna, P. Mogensen, B. Palm, Distributed thermal response test on a u-pipe borehole heat exchanger, 11th International Conference on Thermal Energy Storage, Stockholm, Effstock, June 14-17 (2009)

3. C. Zhang, Z, Guo, Y. Liu, X. Cong, D. Peng, Renew. Sust. Energ. Rev. 40, 851-867 (2014)

4. W.A. Austin, Development of an in situ system for measuring ground thermal properties, Master thesis (Oklahoma State University, 1998)

5. S. Javed, J.D. Spitler, P. Fahlén, ASHRAE Trans. 117, 1, 13-21 (2011)

6. W. Austin, C. Yavuzturk, J.D. Spitler, ASHRAE Trans. 106, 365-379 (2000)

7. B. Sanner, M. Reuss, E. Mands, J. Müller, Thermal response test - experiences in Germany, Proceedings to Terrastock, Campus Universität Stuttgard, 177-182 (2000)

8. S. Gehlin, G. Hellström, Renew. Energy 28, 2221-2235 (2003)

9. A. Liuzzo-Scorpo, B. Nordell, S. Gehlin, Geothermics 56, 119-127 (2015)

10. T. Śliwa, A. Gonet, 28, 3 (2011)

11. PORT PC, Wytyczne projektowania, wykonania i odbioru instalacji z pompami ciepła, część 1 - Dolne źródła do pomp ciepła, 01/2013 